\title{
GENOME SIZE IN HUMULUS LUPULUS L. AND H. JAPONICUS SIEBOLD \& ZUCC. (CANNABACEAE)
}

\author{
ALEKSANDRA GRABOWSKA-JOACHIMIAK ${ }^{1}$, ELWIRA SLIWINSKA ${ }^{2}$, \\ Magdalena PiguŁA ${ }^{1}$, URSZUla SKOMRA ${ }^{3}$, ANDRZEJ J. JOACHIMIAK ${ }^{4}$ \\ ${ }^{1}$ Cytogenetics Group in the Department of Plant Breeding and Seed Science, \\ The Agricultural University of Cracow \\ Łobzowska 24, 31-140 Kraków, Poland \\ e-mail: rrjoachi@cyf-kr.edu.pl \\ ${ }^{2}$ Laboratory of Molecular Biology and Cytometry, \\ Department of Genetics and Plant Breeding, University of Technology and Agriculture \\ Kaliskiego 7, 85-796 Bydgoszcz, Poland \\ ${ }^{3}$ Department of Breeding and Agriculture of Special Crops \\ Institute of Soil Science and Plant Cultivation \\ Czartoryskich 8, 24-100 Puławy, Poland \\ ${ }^{4}$ Department of Plant Cytology and Embryology \\ Institute of Botany, Jagiellonian University \\ Grodzka 52, 31-044 Kraków, Poland
}

(Received: October 10, 2005. Accepted: December 15, 2005)

\begin{abstract}
We analysed chromosome lengths, karyotype structure, and nuclear DNA content (flow cytometry) in diploid $(2 \mathrm{n}=20)$ and triploid $(2 \mathrm{n}=30)$ European $H$. lupulus var. lupulus, American H. lupulus var. neomexicanus $(2 \mathrm{n}=20)$ and Japanese ornamental hop, $H$. japonicus $(\mathrm{F} / 2 \mathrm{n}=16 ; \mathrm{M} / 2 \mathrm{n}=17)$. Diploid female representatives of $H$. lupulus var. lupulus and H. l. var. neomexicanus differed in total length of the basal chromosome set (23.16 um and 25.99 $\mu \mathrm{m}$, respectively) and nuclear 2C DNA amount (5.598 pg and $6.064 \mathrm{pg}$ ) but showed similar karyotype structure. No deviation from the additivity, both in chromosome length and 2C DNA amount was evidenced in triploid monoecious $H$. lupulus $(2 \mathrm{n}=30, \mathrm{XXY})$. H. japonicus showed different karyotype structure, smaller basal chromosome set $(\mathrm{F} / 18.04 \mu \mathrm{m}, \mathrm{M} / 20.66 \mu \mathrm{m})$ and lower nuclear DNA amount $(\mathrm{F} / 3.208 \mathrm{pg}$ and $\mathrm{M} / 3.522 \mathrm{pg})$. There are first evaluations of nuclear genome size in diploid, not commercial representative of European $H$. lupulus var. lupulus and American H. lupulus var. neomexicanus and first attempt to determine the absolute male and female genome size in two Humulus species.
\end{abstract}

KEY WORDS: Humulus lupulus, H. japonicus, flow cytometry, DNA amount, karyotype, sex chromosomes.

\section{INTRODUCTION}

The genus Humulus, one of two genera in the Cannabaceae family contains three species: $H$. lupulus, $H$. japonicus (=H. scandens (Lour.) Merr.) and H. yunnanensis (Small 1978). Both H. lupulus (European common hop) and H. japonicus (Japanese ornamental hop) are dioecious, climbing plants with sex chromosomes (Winge 1929) and sex determination system based on X/autosome balance (Parker and Clark 1991; Shepard et al. 2000). There are no reports on chromosome number and sex determination in H. yunnanensis.
H. lupulus, a perennial species important in the brewing industry is usually diploid with $2 \mathrm{n}=20$. The simplest sex chromosome system described for hop plants of European origin is $\mathrm{XX} / \mathrm{XY}$, where males are heterogametic with the Y smaller than the X chromosome (Winge 1929; Parker 1990; Parker and Clark 1991; Shepard et al. 2000). In common hop, X/autosome ratio of 0.5 or less gives male phenotype, while a ratio of 1.0 gives rise to female plants. Sporadically, at the diploid and more frequently at the polyploid level monoecious plants can be observed (Haunold 1991). Triploids $(2 n=3 x=27+X X Y, X / A=0.67)$ are generally of male phenotype with only a few terminal female 
inflorescence within male panicles (Parker and Clark 1991; Shepard et al. 1999, 2000). Occasionally, on such monoecious triploid plants bisexual flowers are formed (Shepard et al. 2000).

Small (1978) separated wild H. lupulus into five botanical varieties, each of them being, in author's opinion, geographically and morphologically distinct i.e. H. lupulus var. cordifolius (Japanese indigenous), H. lupulus var. neomexicanus, $H$. lupulus var. lupuloides (North American indigenous), H. lupulus var. pubescens (American Midwestern) and $H$. lupulus var. lupulus (European indigenous).

$H$. japonicus is an annual decorative vine with chromosome constitution $2 n=14+X X$ for females and $2 n=14+X Y_{1} Y_{2}$ for males, that remains the sex chromosome system of $R u$ mex acetosa (Parker and Clark 1991; Shepard et al. 1999). The sex chromosomes in H. japonicus are the largest in the complement, and the Ys are only slightly smaller than the X (Parker 1990; Parker and Clark 1991). It is still an unresolved question whether different karyotype organization in two Humulus species resulted from different organization of similar genetic material (at least in respect of nuclear DNA amount) or from the other, more substantial changes on the genomic level (chromosome duplications/deletions, dysploid reduction, etc.).

In hops, especially in $H$. lupulus, the morphological differences between mitotic chromosomes are small, thus their exact identification and classification is practically not available using standard cytogenetic methods. The sex chromosomes in these plants were predominantly recognised during meiotic prophase or metaphase I (Ono 1955; Parker and Clark 1991; Shepard et al. 1999). However, the more precise karyotype structure of $H$. lupulus based on combined data from FISH signals and DAPI banding was presented recently by Karlov et al. (2003). The authors identified the Y chromosome as the shortest and deprived of fluorescent signals, whereas the $\mathrm{X}$ as middle sized with characteristic interstitial DAPI band on its short arm.

The absolute size (C-value) seems to be the other very important general character of a plant genome. C-value, as a 'key diversity character with many uses' (Bennett and Leitch 2005), shows not only an effect on many traits of organisms, but also on quality and utility of genetic fingerprints (Fay et al. 2005), commonly used by plant breeders for more detail germ-plasm characterization. Moreover, the knowledge of absolute genome size is essential for the detection of interspecific and intervarietal differences, polyploid/aneuploid identification and inter-laboratory comparisons of DNA data. Unfortunatelly, information about nuclear DNA amount in Humulus species and varieties are scant and inconsistent. Cytometric DNA measurements were performed only in some, mainly triploid $H$. lupulus cultivars for the flow cytometric identification of putative aneuploids (Šesek et al. 2000), in vitro induced tetraploids (Roy et al. 2001) or sexually derived polyploids (Beatson et al. 2003). Absolute 2C DNA values were published by Šesek et al. (2000), for triploid synthetics only, and recently by Zonneveld et al. (2005), most probably for diploid forms, although the chromosome numbers of analysed plants were not determined by the authors. The size of basal chromosome set (DNA content of a monoploid genome, 1Cx-value, according to Greilhuber et al. 2005) of $H$. lupulus calculated from the Sesek's data (about $2.3 \mathrm{pg}$ ) is much lower than that mentioned by Zonneveld et al. (2005) (two accessions, H. l. var. cordifolia $-2.9 \mathrm{pg}$ and $H . l$. cv. Brambling cross $-3.1 \mathrm{pg}$ ). The reasons for these differences in DNA estimations remain unclear. They can result from the intraspecific 2C DNA polymorphisms, and/or from the deviation from the additivity in triploid forms analysed by Šesek et al. (2000). It is well known that polyploids can show different, unexpected changes (deviations from additivity) in nuclear DNA amount (Ohri 1998).

Nuclear DNA amount in $H$. japonicus was analysed only once, by Zonneveld et al. (2005). It turned out that nuclear 2C DNA amount in this species (3.4 pg) is considerably lower than in diploid representatives of $H$. lupulus ( $\sim 6 \mathrm{pg}$ ). Unfortunatelly, chromosome number and sex of analysed plants were not mentioned in the paper.

The knowledge of genome sizes in Humulus should be helpful for recognition of existing differences between basal diploid taxa belonging to this interesting genus, especially between botanical and commercial varieties of $H$. lupulus and between $H$. lupulus and $H$. japonicus, two species differing by chromosome number $(2 \mathrm{n}=20$ and $2 n=16 / 17)$ and sex chromosome system (XX/XY and $\mathrm{XX} / \mathrm{XY}_{1} \mathrm{Y}_{2}$ ). To broaden the knowledge on this field we estimated the nuclear DNA content in two botanical varieties of $H$. lupulus (European var. lupulus and American var. neomexicanus), and Japanese ornamental hop, $\mathrm{H}$. japonicus.

\section{MATERIALS AND METHODS}

\section{Plant material}

Humulus lupulus - plants used in this study, all derived from Institute of Soil Science and Plant Cultivation, Puławy, Poland, are listed bellow:

H. lupulus cv.'Lubelski' - Polish diploid cultivar, released in 1964 as a noble aroma hop, is cultivated in Poland to date on an area of about 800 ha. Was used for crossing for its aroma character; ' $3 / 19$ ' - triploid monoecious plants, developed in Puławy as seedling selection of cross made in 1991 between the diploid cultivar Talisman and male genotype ' $5 / 23$ ' derived from a cross of cv. 'Lubelski' and male hop from Jugoslavia. Was used for crossing as a male parent for its early maturity and high alpha acid content in pollen; 'B1' - male wild plants, collected in 1997 from natural population near Polanczyk, Bieszczady Mts., Poland. Was used for crossing for its early maturity and moderate resistance to hop downy mildew; H. lupulus var. neomexicanus A. Nelson \& Cockerell - female plants obtained from Hop Institute in Żytomierz (Ukraine), in Puławy hop collection from 1994. Very late in maturity, therefore it has never been used for crossing in Poland;

Humulus japonicus - male and female plants were grown from purchased seeds (collected in Plant Breeding Enterprise 'W. Legutko', Poland).

The young plants were grown in flower-pots, in a greenhouse (Department of Plant Breeding and Seed Science, The Agricultural University of Cracow, Poland), then they were grown in flower-pots under open- air conditions.

\section{Chromosome analysis}

The root tips were collected, pretreated with ice-cold water for $24 \mathrm{~h}$, and fixed in 3:1 absolute alcohol: glacial acetic acid for $3 \mathrm{~h}$. After rinsing in distilled water, fixed root tips 

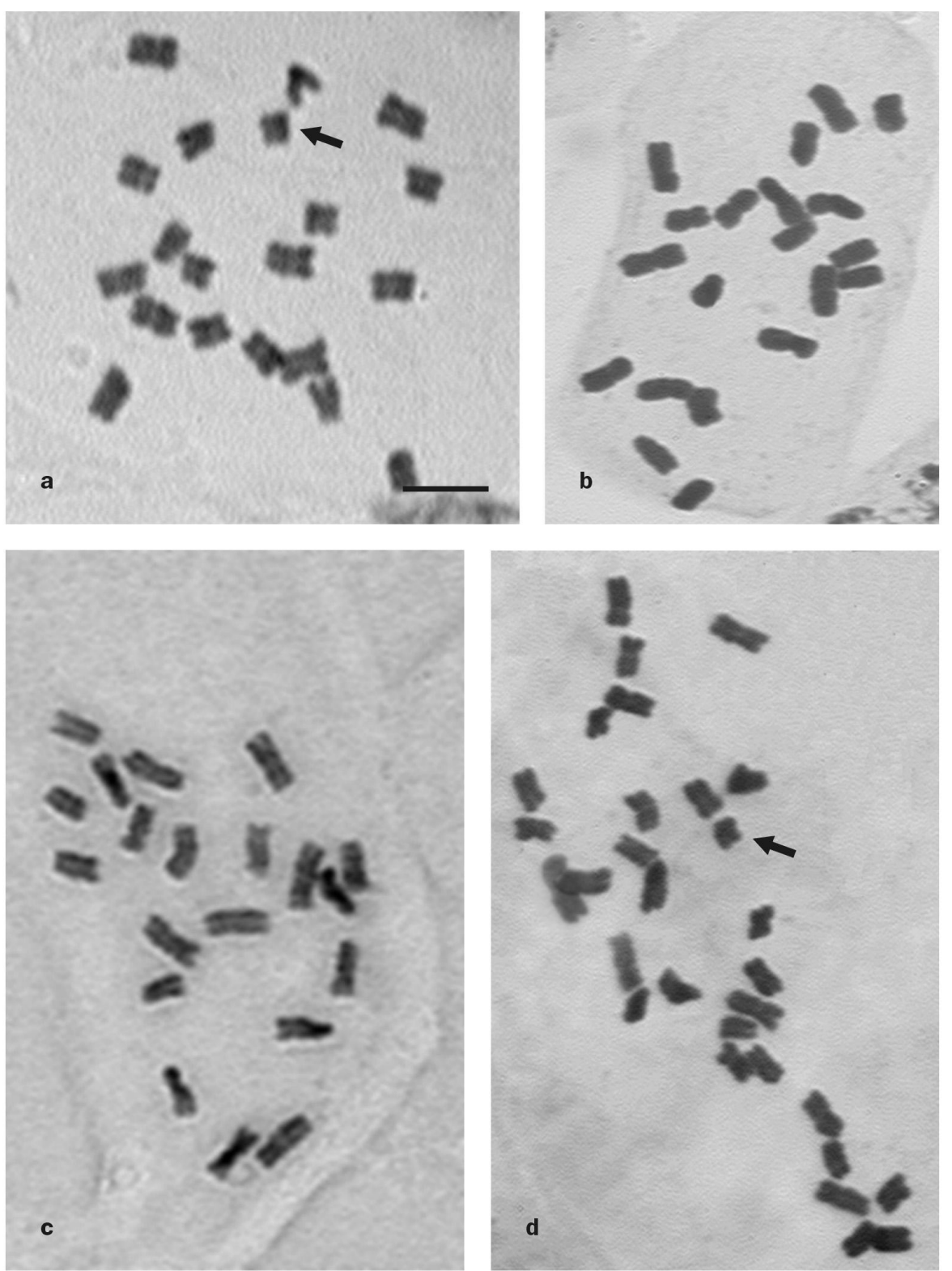

Fig. 1. Metaphase plates of H. lupulus var. lupulus (a, b, d), and H. lupulus var. neomexicanus (c); a - diploid male [B1]; b - diploid female (cv. Lubelski); $\mathrm{c}$-diploid female; $d$-triploid monoecious plant [3/19]; Y chromosomes arrowed; bar - $5 \mu \mathrm{m}$.

were hydrolysed in $1 \mathrm{M} \mathrm{HCL}$ at $60^{\circ} \mathrm{C}$ for $12 \mathrm{~min}$., Feulgenstained with pararosaniline (Sigma, St. Louis, Mo.) for $2 \mathrm{~h}$ at room temperature and then squashed in $45 \%$ acetic acid.

For chromosome measurements only well spreaded metaphase plates were selected. Finally, ten metaphase plates of $H$. lupulus cv. Lubelski, $H$. lupulus 'B1', H. lupulus var. neomexicanus, and $H$. japonicus (F/M) and five plates of triploid monoecious ' $3 / 19$ ' plant were analysed. Chromosome images were captured, processed and measured using a CCD camera and Lucia G (Laboratory Imaging Ltd., Praha, Czech Republic) software.

\section{DNA measurements}

Young leaves were used for the flow cytometric analysis of DNA content estimation. Samples were prepared according to Galbraith et al. (1983), with some minor modifica- tions. Plant tissue (of the plant in question and of the internal standard, simultaneously) was chopped with a sharp razor blade in a plastic Petri dish with $1 \mathrm{ml}$ nucleus-isolation buffer $\left(0.1 \mathrm{M}\right.$ Tris, $2.5 \mathrm{mM} \mathrm{MgCl} 2.6 \mathrm{H}_{2} \mathrm{O}, 85 \mathrm{mM} \mathrm{NaCl}$, $0.1 \% \mathrm{v} / \mathrm{v}$ Triton $\mathrm{X}-100 ; \mathrm{pH} 7.0)$, supplemented with propidium iodide $(50 \mu \mathrm{g} / \mathrm{ml})$ and ribonuclease $\mathrm{A}(50 \mu \mathrm{g} / \mathrm{ml})$. After chopping, the suspension was passed through a 50 $\mu \mathrm{m}$ mesh nylon filter. For each sample, 5000-7000 nuclei were analysed using a Partec CCA (Münster, Germany) flow cytometer, equipped with an argon laser. For each entry 10 measurements of separate nucleus isolation from different plants were made. Histograms were analysed using a DPAC v.2.2 computer program. Petunia hybrida cv. $\mathrm{P} \times$ Pc6 (2C $=2.85$ pg/nucleus; Marie and Brown 1993) was used as the internal standard for H. lupulus and Zea mays CEE-777 (2C=5.43 pg/nucleus; Lysák and Doležel 1998) 
TABLE 1. Chromosome lengths of diploid female H. lupulus plants. Lub - cv. 'Lubelski', Neo - var. neomexicanus, $\mathrm{x}^{\mathrm{F}}$ - basal female chromosome set $(\mathrm{A}+\mathrm{X}), \%$ - relative length of chromosomes calculated as a percent of $\mathrm{x}^{\mathrm{F}}$; bold - putative $\mathrm{X}$ chromosome.

\begin{tabular}{ccccc}
\hline & \multicolumn{2}{c}{ Lub } & \multicolumn{2}{c}{ Neo } \\
\hline & $\mu \mathrm{m}$ & $\%$ & $\mu \mathrm{m}$ & $\%$ \\
\hline 1 & $2.87 \pm 0.17$ & 12.39 & $3.29 \pm 0.20$ & 12.66 \\
2 & $2.73 \pm 0.18$ & 11.79 & $3.08 \pm 0.24$ & 11.85 \\
3 & $2.57 \pm 0.17$ & 11.10 & $2.91 \pm 0.29$ & 11.20 \\
4 & $2.45 \pm 0.16$ & 10.58 & $2.77 \pm 0.27$ & 10.66 \\
$\mathbf{5}$ & $\mathbf{2 . 3 4} \pm \mathbf{0 . 1 1}$ & $\mathbf{1 0 . 1 0}$ & $\mathbf{2 . 6 4} \pm \mathbf{0 . 2 4}$ & $\mathbf{1 0 . 1 6}$ \\
6 & $2.24 \pm 0.10$ & 9.67 & $2.52 \pm 0.21$ & 9.70 \\
7 & $2.15 \pm 0.09$ & 9.28 & $2.40 \pm 0.17$ & 9.23 \\
8 & $2.10 \pm 0.08$ & 9.07 & $2.28 \pm 0.18$ & 8.17 \\
9 & $1.95 \pm 0.09$ & 8.42 & $2.14 \pm 0.17$ & 8.23 \\
10 & $1.76 \pm 0.11$ & 7.60 & $1.96 \pm 0.23$ & 7.54 \\
\hline $\mathrm{x}^{\mathrm{F}}$ & $23.16 \pm 1.16$ & 100 & $25.99 \pm 2.05$ & 100 \\
\end{tabular}

for $H$. japonicus. Nuclear DNA content was calculated using the linear relationship between the ratio of the $2 \mathrm{C}$ peak positions Humulus/internal standard, on the histogram of fluorescence intensities.

\section{RESULTS}

\section{H. lupulus var. lupulus}

By morphology, chromosomes of $H$. lupulus are hardly recognizable (Fig. 1). Because there are no clear differences in total length and/or arm ratio between the majority of adjoining chromosome pairs, chromosomes derived from each diploid metaphase plate analysed here were arranged by length, and 10 chromosome pairs (from the smallest to the largest) were distinguished arbitrarily. The average lengths of the chromosomes $1-10$ are presented in the Tables 1 and 2

Although $H$. lupulus is long recognized as the dioecious plant with sex chromosome system (Winge 1929; Jacobsen 1957; Westergaard 1958), its sex chromosomes are not easy to identify even in males, possessing heteromorphic sex chromosome pair. Especially the identification of X chromosomes seems to be very difficult because of the lack of the morphological difference between them and the medium-sized autosomes. Karlov et al. (2003) suggested that the $\mathrm{X}$ chromosome, although slightly longer, had substantially the same size and morphology as autosome 4 . Thus, we identified 5th chromosome as the female sex chromosome. The single, shortest chromosome identified here both
TABLE 2. Absolute $(\mu \mathrm{m})$ and relative (\%) chromosome lengths in diploid male $H$. lupulus plant from Bieszczady, $\mathrm{x}^{\mathrm{F}}$ - basal female chromosome set $(\mathrm{A}+\mathrm{X}), \mathrm{x}^{\mathrm{M}}$ - basal male chromosome set $(\mathrm{A}+\mathrm{Y}) ; \%$ - calculated as a percent of $\mathrm{X}^{\mathrm{F}}$; bold - putative $\mathrm{X}$ chromosome.

\begin{tabular}{ccc}
\hline \multicolumn{3}{c}{ Chromosomes } \\
\hline 1 & $\mu \mathrm{m}$ & $\%$ \\
2 & $2.94 \pm 0.11$ & 12.51 \\
3 & $2.79 \pm 0.11$ & 11.88 \\
4 & $2.63 \pm 0.16$ & 11.20 \\
$\mathbf{5}$ & $2.48 \pm 0.13$ & 10.56 \\
6 & $\mathbf{2 . 3 9} \pm \mathbf{0 . 1 0}$ & $\mathbf{1 0 . 1 7}$ \\
7 & $2.28 \pm 0.17$ & 9.71 \\
8 & $2.20 \pm 0.17$ & 9.36 \\
9 & $2.09 \pm 0.16$ & 8.90 \\
10 & $1.94 \pm 0.20$ & 8.26 \\
\hline $\mathrm{Y}$ & $1.75 \pm 0.20$ & 7.45 \\
\hline $\mathrm{x}^{\mathrm{F}}$ & $1.63 \pm 0.11$ & 6.97 \\
$\mathrm{x}^{\mathrm{M}}$ & $23.49 \pm 1.26$ & 100 \\
\hline
\end{tabular}

in diploid males and triploid monoecious plants was most probably the Y chromosome (Fig. 1a, d).

The absolute (in $\mu \mathrm{m}$ ) and relative (calculated as the percent of total length of the basal female set, i.e. $A+X)$ lengths of chromosomes $1-10$ are nearly the same in analysed diploid plants (Tables 1 and 2). They show also similar nuclear DNA amount (females 5.598 pg, males $5.523 \mathrm{pg}$ ) (Table 3$)$, and the observed difference $(0.075 \mathrm{pg}$, i.e. $1.34 \%$ ) probably resulted from the size difference between male and female sex chromosome. The detected length difference between male and female genome is $3.24 \%$ (Table 2 ), thus the difference on the diploid level (total karyotype length) is only $1.62 \%$.

The measured total karyotype length of the triploid monoecious plant was $65.49 \mu \mathrm{m}$, i.e. about 1.5 fold of the karyotype length of diploid plants. Triploid nuclear DNA content was also about one and a half times higher than this of diploid (Table 3, Fig. 2).

\section{H. lupulus var. neomexicanus}

In comparison to the female plants of cv. 'Lubelski', the analysed female specimens of this botanical variety show higher nuclear DNA amount (6.064 pg) and slightly longer chromosome set (Tables 1 and 3). Despite of these differences, the relative chromosome lengths in two compared $H$. lupulus varietes (calculated as the percent of total length of the basal female chromosome set) were similar (Table 1).

TABLE 3. Chromosome numbers (2n) and nuclear 2C DNA amounts (pg) of analysed hops. $2 \mathrm{n}-$ somatic chromosome number, $2 \mathrm{C}-2 \mathrm{C}$ DNA amount. Lub - cv. 'Lubelski', Bie - from Bieszczady, 3/19 - triploid monoecious plant, Neo - var. neomexicanus.

\begin{tabular}{|c|c|c|c|c|c|c|}
\hline & \multicolumn{2}{|c|}{ Female } & \multicolumn{2}{|c|}{ Male } & \multicolumn{2}{|c|}{ Monoecious } \\
\hline & $2 n$ & $2 \mathrm{C}$ & $2 n$ & $2 \mathrm{C}$ & $2 n$ & $2 \mathrm{C}$ \\
\hline \multicolumn{7}{|l|}{ H. lupulus } \\
\hline Lub & 20 & $5.598 \pm 0.044$ & & & & \\
\hline $\mathrm{Bie}$ & & & 20 & $5.523 \pm 0.055$ & & \\
\hline $3 / 19$ & & & & & 30 & $8.956 \pm 0.114$ \\
\hline $\mathrm{Neo}$ & 20 & $6.064 \pm 0.048$ & & & & \\
\hline H. japonicus & 16 & $3.208 \pm 0.028$ & 17 & $3.522 \pm 0.117$ & & \\
\hline
\end{tabular}



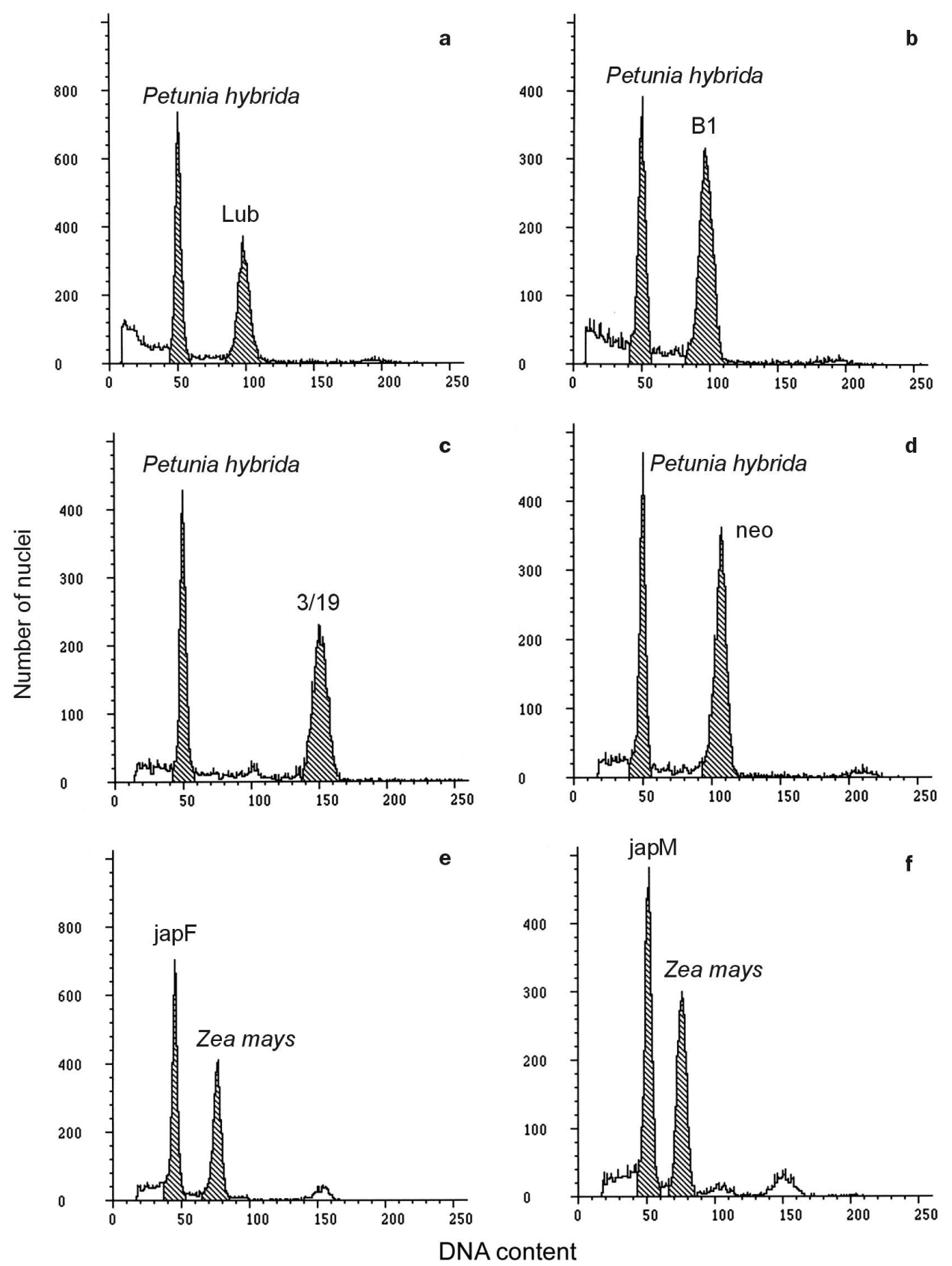

Fig. 2. DNA-histograms of nuclei isolated simultaneously from leaves of Humulus and internal standards; H. lupulus var. lupulus (a-c), H. lupulus var. neomexicanus $(\mathrm{d})$, and $H$. japonicus $(\mathrm{e}, \mathrm{f}) ; \mathrm{Lub}-\mathrm{var}$. Lubelski $(2 \mathrm{n}=20), \mathrm{B} 1-$ male plant from Bieszczady $(2 \mathrm{n}=20), 3 / 19-$ triploid monoecious plant $(2 \mathrm{n}=30)$, neo - var. neomexicanus, female plant $(2 \mathrm{n}=20)$, japF - female plant $(2 \mathrm{n}=16)$, japM - male plant $(2 \mathrm{n}=17)$.

\section{H. japonicus}

H. japonicus shows a different somatic number of chromosomes $(2 \mathrm{n}=16$ in females and $2 \mathrm{n}=17$ in males) (Fig. 3 ) and different sex chromosome system $\left(\mathrm{XX} / \mathrm{XY}_{1} \mathrm{Y}_{2}\right)$. The $\mathrm{X}$ chromosomes in this species are the largest in the complement and the $\mathrm{Y}$ chromosomes $\left(\mathrm{Y}_{1}\right.$ and $\left.\mathrm{Y}_{2}\right)$ are larger than the largest autosome pair, however they are of similar size and shape to the $\mathrm{X}$ (Table 4). The ornamental hop differ from common hop not only by chromosome number but also by the genome size (Table 3, Fig. 2). Its basal female chromosome set contains less DNA (1.604 pg) than the set of H. lupulus var. lupulus (2.799 pg) and H. lupulus var. neomexicanus (3.032 pg) and is much shorter (18.04 $\mu \mathrm{m})$ (Table 4). Because of the presence of two large $\mathrm{Y}$ chromosomes the basal male chromosome set in this species is much bigger than the female one. Detected length difference between basal male and female set (i.e. $\mathrm{A}+\mathrm{Y}_{1} \mathrm{Y}_{2}$ and $\mathrm{A}+\mathrm{X}$ ) in this species is $14.52 \%$ (Table 4), thus the difference on the diploid level is $7.26 \%$. The de- 

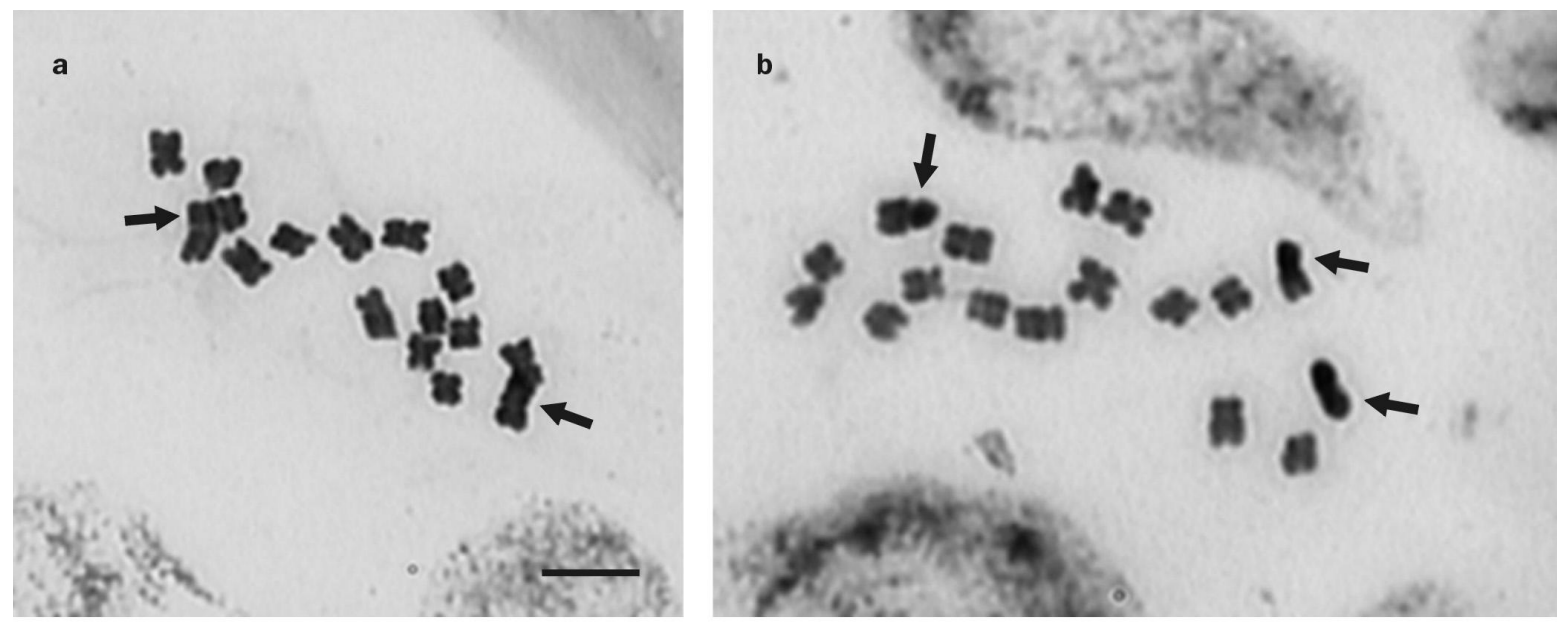

Fig. 3. Metaphase plates of $H$. japonicus; $\mathrm{a}$ - female $(2 \mathrm{n}=16) ; \mathrm{b}-$ male $(2 \mathrm{n}=17)$; sex chromosomes arrowed; bar $-5 \mu \mathrm{m}$.

TABLE 4. Chromosome lengths of H. japonicus. $\mathrm{x}^{\mathrm{F}}-$ basal female chromosome set $(\mathrm{A}+\mathrm{X}), \mathrm{x}^{\mathrm{M}}$ - basal male chromosome set $\left(\mathrm{A}+\mathrm{Y}_{1} \mathrm{Y}_{2}\right), \%$ - relative length of chromosomes calculated as a percent of $\mathrm{X}^{\mathrm{F}}$; bold $\mathrm{X}$ chromosome.

\begin{tabular}{lcc}
\hline \multicolumn{3}{c}{ H. japonicus } \\
\hline $\mathbf{1}$ & $\mu \mathrm{m}$ & $\%$ \\
2 & $\mathbf{3 . 1 1} \pm \mathbf{0 . 2 9}$ & $\mathbf{1 7 . 2 4}$ \\
3 & $2.53 \pm 0.22$ & 14.02 \\
4 & $2.38 \pm 0.22$ & 13.19 \\
5 & $2.25 \pm 0.20$ & 12.47 \\
6 & $2.13 \pm 0.17$ & 11.48 \\
7 & $2.01 \pm 0.16$ & 11.14 \\
8 & $1.88 \pm 0.18$ & 10.43 \\
\hline $\mathrm{Y} 1$ & $1.75 \pm 0.15$ & 9.70 \\
$\mathrm{Y} 2$ & $2.98 \pm 0.23$ & 16.52 \\
\hline $\mathrm{x}^{\mathrm{F}}$ & $2.75 \pm 0.24$ & 15.24 \\
$\mathrm{x}^{\mathrm{M}}$ & $18.04 \pm 1.74$ & 100 \\
\hline
\end{tabular}

tected difference in 2C DNA content between male and female nuclei is even greater $(9.79 \%)$ (Table 3$)$.

\section{DISCUSSION}

The different sex chromosome system (XX/XY in $H$. lupulus and $\mathrm{XX} / \mathrm{XY}_{1} \mathrm{Y}_{2}$ in $H$. japonicus), and the existing $\mathrm{X} / \mathrm{Y}$ length differences make the direct comparisons of 2C DNA amounts in different hop lineages difficult. It seems, however, that the good indicator of the genome size in hops could be DNA amount in the single female chromosome set, $\mathrm{A}+\mathrm{X}\left(\mathrm{Cx}^{\mathrm{F}}\right)$. The calculated $\mathrm{Cx}^{\mathrm{F}} \mathrm{s}$ in diploid representatives of $H$. lupulus (2.799 pg in $H$. lupulus var. lupulus and $3.032 \mathrm{pg}$ in $H$. lupulus var. neomexicanus) are considerably higher than in $H$. japonicus $(1.604 \mathrm{pg})$. It suggests that the observed karyotypic difference between the two species $(2 \mathrm{n}=2 \mathrm{x}=20 v$ s. $2 \mathrm{n}=2 \mathrm{x}=16 / 17)$ resulted not only from the different organization of the nuclear material.

Unfortunately, there are still no reports about nuclear genome of the third species belonging to this genus, $H$. yunnanensis. This controversial endemic form was recognized as a separate species by Small (1978) on the basis of the morphological analysis of herbarium specimens. The author suggested that this hop, although almost always mistaken for $H$. lupulus, is more closely related to $H$. japonicus than to $H$. lupulus. The chromosomal evaluation should clear this problem, but we were not able to obtain living $H$. yunnanensis plants for analysis.

Two of the analysed $H$. lupulus varieties (var. lupulus and var. neomexicanus) show a nearly identical karyotype composition (in respect to the relative lengths of particular chromosome types) and $\sim 8 \%$ difference in the nuclear genome size (Table 1). It suggests a rather small, equal DNA change in all chromosomes, characteristic for spontaneous deletions/insertions or changes in the copy number of interspersed elements (Kubis et al. 1998; Hartl 2000; Kidwell 2002). Small differences in genome size between different botanical $H$. lupulus varieties can be also deduced from Zonneveld et al. (2005) data. The 1C DNA value (2.9 pg) estimated by authors for $H$. lupulus var. cordifolia is very close to H. l. var. lupulus ( 2.8 pg) and H. l. var. neomexicanus ( 3.0 pg).

It cannot be also excluded, that there are some differences in nuclear DNA amounts between different $H$. $l$. var. lupulus cultivars, because DNA value $\left(\mathrm{Cx}_{\mathrm{F}}^{\mathrm{F}}=2.8 \mathrm{pg}\right)$ obtained for cv. Lubelski (our study) differ from value $\left(\mathrm{Cx}^{\mathrm{F}}=3.1\right.$ pg) for cv. Bramblig cross (Zonneveld et al. 2005). All commercial plants are females, thus the observed inconsistence cannot result from sex difference. It was most probably due to the different internal standards (Petunia hybrida vs. Agave americana). On the other hand, H. japonicus 2C DNA values obtained by us (males $\sim 3.5 \mathrm{pg}$, females $\sim 3.2 \mathrm{pg}$ ) and by Zonneveld et al. (2005) (3.4 pg) are very similar despite of the use of different standards (Zea mays vs. A. americana).

Triploid monoecious $H$. lupulus (with karyotype formula $3 \mathrm{~A}+\mathrm{XXY}$ ), shows about 9 pg DNA in $\mathrm{G}_{1}$ nuclei, thus the size of basal genome of this plant is about $3.0 \mathrm{pg}$, close to estimated for diploid representatives of this species. It shows that the intraspecific triploidization in hop was not accompanied with the major changes in nuclear DNA content. Although it was recently suggested that nuclear DNA amount in majority of polyploid plants is rather less than expected (Levy and Feldman 2002; Leitch and Bennett 
2004), both additive and non-additive effects on the 2C DNA level were reported for different polyploid plant taxa (Ohri 1998). Most probably the deviation from additivity depends on the difference between the parental genomes and the ploidy level (Albach and Greilhuber 2004). Thus, DNA values of autotriploids should be near the sum of the DNA values of their parents.

2C DNA value estimated by us ( $\sim 9 \mathrm{pg})$ is much higher than that obtained by Šesek et al. (2000) for Slovenian triploid cultivars ( $6.8 \mathrm{pg}$, i.e. about $2.3 \mathrm{pg}$ per basal chromosome set). Such a large inconsistency was most probably due to the different internal standard (Trifolium repens) and fluorochrome used for DNA estimation. The fluorochrome used by Šesek et al. (2000) was 4',6-diamidino-2-phenylindole (DAPI), the dye showing base preference (AT), and in our study intercalating dye, propidium iodide (PI), was applied. It has been shown that the use of dyes showing base preference (e.g. DAPI) may lead to large errors in genome size estimation, thus the use of PI is recommended for flow cytometric determination of DNA amount in plants (Doležel et al. 1998; Johnston et al. 1999). Moreover, for calculation of DNA content in H. lupulus Šesek et al. (2000) used for internal standard the value estimated by Arumuganathan and Earle (1991), obtained with PI and not DAPI, which additionally increased the error in their genome size estimations.

It has been suggested that structurally distinct sex chromosomes have evolved from a pair of homologues (Charlesworth 1991; Liu et al. 2004). In many animal taxa Y chromosome is shorter than $\mathrm{X}$ and genetically degenerated (Charlesworth and Charlesworth 1998). However, in plants possessing well recognizable sex chromosomes, Y chromosome (or sum of $\mathrm{Y}$ chromosomes in $\mathrm{XX} / \mathrm{XY}_{1} \mathrm{Y}_{2}$ system) is usually longer than the $\mathrm{X}$ (Parker 1990; Ainsworth 2000). For instance, in the model plant Silene latifolia and in its close relative, $S$. dioica (XX/XY sex chromosome system) the $\mathrm{X}$ and $\mathrm{Y}$ chromosome differ by factor $\sim 1.4$, both by length and DNA amount (Grabowska-Joachimiak and Joachimiak 2002). In this point, $H$. lupulus with much shorter Y chromosome (Table 2), is the only known exception to the rule. Our measurements of the mitotic chromosomes in males revealed $\mathrm{X}: \mathrm{Y}$ size ratio approximated to 1.5 , that is in agreement with the previous data estimated for $\mathrm{X}$ and $\mathrm{Y}$ chromosomes in male meiosis, reported by Shepard et al. (2000). The length difference between male and female chromosome complement in this species was only $1.62 \%$. A very similar difference $(1.71 \%)$ can be deduced from the data published by Karlov et al. (2003).

\section{ACKNOWLEDGEMENTS}

We thank Dr. Spencer C. Brown (Institut des Sciences Végétales, CNRS, Gif-sur-Yvette, France) and Dr. J. Doležel (Institute of Experimental Botany, Olomouc, Czech Republic) for kindly providing the seeds of internal standards, Petunia hybrida and Zea mays, respectively.

\section{LITERATURE CITED}

ALBACH D.C., GREILHUBER J. 2004. Genome size variation and evolution in Veronica. Ann. Bot. 94: 897-911.
AINSWORTH C. 2000. Boys and girls come out to play: the molecular biology of dioecious plants. Ann. Bot. 86: 211-221.

ARUMUGANATHAN K., EARLE E.D. 1991. Nuclear DNA content of some important plant species. Plant Mol. Biol. Rep. 9: 208-218.

BEATSON R.A., FERGUSON A.R., WEIR I.E., GRAHAM L.T., ANSELL K.A., DING H. 2004. Flow cytometric identification of sexually derived polyploids in hop (Humulus lupulus L.) and their use in hop breeding. Euphytica 134: 189-194.

BENNETT M.D., LEITCH I.J. 2005. Nuclear DNA amounts in Angiosperms: progress, problems and prospects. Ann. Bot. 95: 45-90.

CHARLESWORTH B. 1991. The evolution of sex chromosomes. Science 251: 1030-1033.

CHARLESWORTH B., CHARLESWORTH D. 1998. Some evolutionary consequences of deleterious mutations. Genetica 102/103: 3-19.

DOLEŽEL J., GREILHUBER J., LUCRETTI S., MEISTER A., LYSÁK M.A., NARDI L., OBERMAYER R. 1998. Plant genome size estimation by flow cytometry: inter-laboratory comparison. Ann. Bot. 82 (Suppl. A): 17-26.

FAY M.F., COWAN R.S., LEITCH I.J. 2005. The effects of nuclear DNA content (C-value) on the quality and utility of AFLP fingerprints. Ann. Bot. 95: 237-246.

GALBRAITH D.W., HARKINS K.R., MADDOX J.M., AYRES N.M., SHARMA D.P., FIROOZABADY E. 1983. Rapid flow cytometric analysis of the cell cycle in intact plant tissues. Science 220: 1049-1051.

GRABOWSKA-JOACHIMIAK A., JOACHIMIAK A. 2002. C-banded karyotypes of two Silene species with heteromorphic sex chromosomes. Genome 45: 243-252.

GREILHUBER J., DOLEŽEL J., LYSÁK M.A., BENNETT M.D. 2005. The origin, evolution and proposed stabilization of the terms 'genome size' and 'C-value' to describe nuclear DNA contents. Ann. Bot. 95: 255-260.

HARTL D.L. 2000. Molecular melodies in high and low C. Nature Rev. Genet. 1: 145-149.

Haunold A. 1991. Cytology and cytogenetics of hops. In: Tsuchiya T. and Gupta P.K. (eds.), Chromosome engineering in plants: genetics, breeding, evolution. Elsevier, New York, pp. 551-563.

JACOBSEN P. 1957. The sex chromosomes in Humulus. Hereditas 43: 357-370.

JOHNSTON J.S., BENNETT M.D., RAYBURN A.L., GALBRAITH D.W., PRICE H.J. 1999. Reference standards for determination of DNA content of plant nuclei. Am. J. Bot. 86: 609-613.

KARLOV G.I., DANILOVA T.V., HORLEMANN C., WEBER G. 2003. Molecular cytogenetics in hop (Humulus lupulus L.) and identification of sex chromosomes by DAPI-banding. Euphytica 132: 185-190.

KIDWELL M.G. 2002. Transposable elements and the evolution of genome size in eukaryotes. Genetica 115: 49-63.

KUBIS S., SCHMIDT T., HESLOP-HARRISON J.S. 1998. Repetitive DNA elements as a major component of plant genomes. Ann. Bot. 82 (Suppl. A): 45-55.

LEITCH I.J., BENNETT M.D. 2004. Genome downsizing in polyploid plants. Biol. J. Linn. Soc. 82: 651-663.

LEVY A.A., FELDMAN M. 2002. The impact of polyploidy on grass genome evolution. Plant Physiol. 130: 1587-1593.

LIU Z.P., MOORE P.H., MA H., ACKERMAN C.M., RAGIBA M., YU Q., PEARL H., KIM M.S., CHARLTON J.W., STILES J.I., ZEE F.T., PATERSON A.H., MING R. 2004. A primitive $\mathrm{Y}$ chromosome in papaya marks incipient sex chromosome evolution. Nature 247: 348-352.

LYSÁK M.A., DOLEŽEL J. 1998. Estimation of nuclear DNA content in Sesleria (Poaceae), Caryologia 52: 123-132.

MARIE D., BROWN S.C. 1993. A cytometric exercise in plant DNA histograms, with $2 \mathrm{C}$ values for 70 species. Biol. Cell. 78: 41-51. 
OHRI D. 1998. Genome size variation and plant systematics. Ann. Bot. 82 (Suppl. A): 75-83.

ONO T. 1955. Studies in hop. I. Chromosomes of common hop and its relatives. Bull. Brew. Sci. 2: 1-65.

PARKER J.S. 1990. Sex chromosomes and sexual differentiation in flowering plants. Chromosomes Today 10: 187-198.

PARKER J.S., CLARK M.S. 1991. Dosage sex-chromosome systems in plants. Plant Sci. 80: 79-92.

ROY A.T., LEGGETT G., KOUTOULIS A. 2001. In vitro tetraploid induction and generation of tetraploids from mixoploids in hop (Humulus lupulus L.). Plant Cell Rep. 20: 489-495.

SHEPARD H., PARKER J., DARBY P., AINSWORTH C.C. 1999. Sex expression in hop (Humulus lupulus L. and H. japonicus Sieb. et Zucc.): floral morphology and sex chromosomes. In: Sex determination in plants. Ainsworth C.C. (ed.). BIOS Scientific Publishers Ltd, Oxford, pp. 137-148.
SHEPARD H.L., PARKER J.S., DARBY P., AINSWORTH C.C. 2000. Sexual development and sex chromosomes in hop. New Phytol. 148: 397-411.

SMALL E. 1978. A numerical and nomenclatural analysis of morpho-geographic taxa of Humulus. Sys. Bot. 3: 37-76.

ŠESEK P., ŠUŠTAR-VOZLIČ J., BOHANEC B. 2000. Determination of aneuploids in hop (Humulus lupulus L.) using flow cytometry. Pflugers Arch. - Eur. J. Physiol. 439 (Suppl.): R16-R18.

WESTERGAARD M. 1958. The mechanism of sex determination in dioecious flowering plants. Adv. Genet. 9: 217-281.

WINGE O. 1929. On the nature of sex chromosomes in Humulus. Hereditas 12: 53-63.

ZONNEVELD B.J.M., LEITCH I.J., BENNETT M.D. 2005. First nuclear DNA amounts in more than 300 Angiosperms. Ann. Bot. 96: 229-244. 